\title{
Functional Dependence among older adults receiving care from Family Health Strategy teams
}

\section{Abstract}

Objective: To evaluate functional dependence among older adults receiving care from Family Health Strategy (FHS) teams, in Montes Claros, Minas Gerais, Brazil, identifying associated factors. Methods: A cross-sectional and analytical study with randomly selected older adults was performed. The instrument used was BOMFAQ (the Brazilian Older Americans Resources and Services Multidimensional Functional Assessment Questionnaire). Data collection was performed by trained staff in the homes of the older adults. Sociodemographic, economic data, living habits, health care, morbidities and Activities of Daily Living (ADL) were evaluated. In addition to descriptive analysis, factors associated with functional dependence were identified using the chi-square test, followed by hierarchical multiple analysis using Poisson regression with robust variance. Results: 1,750 older adults were evaluated. The group was predominantly female, with low schooling. The proportion of the sample considered dependent was $57.0 \%$. The variables associated with functional dependence were: female gender ( $P R=1.19)$; age $\geq 70$ years $(\mathrm{PR}=1.33)$; schooling $\leq 4$ years $(\mathrm{PR}=1.19)$; being unemployed $(\mathrm{PR}=1.43)$; not performing physical activity ( $\mathrm{PR}=1.19)$ or walking $(\mathrm{PR}=1.15)$; not listening to the radio as a leisure activity $(\mathrm{PR}=1.13)$; not having the habit of reading $(\mathrm{PR}=1.17)$; presenting depressive symptoms ( $\mathrm{PR}=1.15)$; hospitalization in the last six months $(\mathrm{PR}=1.18)$; cognitive impairment ( $\mathrm{PR}=1.16)$; insomnia ( $\mathrm{PR}=1.13)$; obesity $(\mathrm{PR}=1.18)$; falls in the

\footnotetext{
Universidade Estadual de Montes Claros, Departamento de Saúde Mental e Coletiva, Centro de Ciências Biológicas e da Saúde. Montes Claros, MG, Brasil.

2 Universidade Estadual de Montes Claros, Departamento de Clínica Médica, Centro de Ciências Biológicas e da Saúde. Montes Claros, MG, Brasil.

3 Universidade Estadual de Montes Claros, Departamento de Odontologia, Centro de Ciências Biológicas e da Saúde. Montes Claros, MG, Brasil.

4 Universidade Estadual de Montes Claros, Departamento de Odontologia, Centro de Saúde da Mulher e da Criança, Centro de Ciências Biológicas e da Saúde. Montes Claros, MG, Brasil.
}

Funding: Conselho Nacional de Desenvolvimento Científico e Tecnológico (CNPq - Processo $\mathrm{n}^{\circ}$ CDSBIP00128-18) e Fundação de Apoio à Pesquisa do Estado de Minas Gerais (FAPEMIG - Processo n ${ }^{\circ}$ CDS - APQ-02965-17).

No funding was received in relation to the present study.

Correspondence

Antônio Prates Caldeira

antonio.caldeira@unimontes.br
Mariano Fagundes Neto Soares' (DD Luciana Colares Maia $^{2}$ (D) Simone de Melo Costa $^{3} \mathbb{D}$ Antônio Prates Caldeira ${ }^{4}$ ID

Keywords: Health of the Elderly. Disability evaluation. Primary Health Care. 
last year ( $\mathrm{PR}=1.11)$; cataracts ( $\mathrm{PR}=1.09)$, spinal problems ( $\mathrm{PR}=1.19)$; urinary incontinence $(\mathrm{PR}=1.25)$; poor circulation ( $\mathrm{PR}=1.09)$ and a negative self-perception of health $(\mathrm{PR}=1.22)$. Conclusion: Functional dependence is multifactorial, but is influenced mainly by the health conditions of older adults.

\section{INTRODUCTION}

The rapid demographic transition observed in Brazil and around the world creates challenges for public health services, as it increases the demand for care aimed at older adults ${ }^{1,2}$. This population group tends to have a higher prevalence of chronicdegenerative diseases, neoplasms and functional losses ${ }^{3}$. The ability to perform activities of daily living (ADLs) is the greatest indicator of functionality among older adults, as it is based on being able to carry out actions required in daily life without help ${ }^{4}$. Activities of daily living involve organic, mental and psychosocial functions. They reflect normal patterns and are commonly divided into basic activities of daily living (BADLs) and instrumental activities of daily living (IADLs).

A state of full functionality or independence for an older adult is influenced by chronic diseases and morbidities inherent to age, but also by physical, cultural, technological and legal environmental barriers ${ }^{6}$. Functionality assessment aims to detect risk conditions, identify demands and the need to use secondary services, and define connections for broad and multidimensional care for older adults. This process allows for an adequate clinical diagnosis that can guide decisions about comprehensive care for the individual.

Functional limitations for older adults should be considered the most important indicator of vulnerability and, therefore, should be the focus of interventions by any professional and/or team responsible for their care. Health professionals, in teams with resolutive capacity, must develop lines of care for older adults, focusing on health promotion and prevention and developing a hierarchical model of care, based on the functional losses that occur frequently over the years ${ }^{7,8}$. In this sense, it is essential that Family Health Strategy (FHS) teams seek to understand the functionality profile of the older population under their care.
Once a loss of functionality is perceived, it is possible for the health team to develop effective and early interventions, allowing older adults and their families to maintain a satisfactory quality of life. Considering the lack of studies on the theme for the northern region of Minas Gerais and the need to raise awareness among FHS teams about the need for training in this area, the present study aimed to assess the functional dependence of older adults receiving care from FHS teams, in a hub city in the region, and also to identify the factors associated with such a condition.

\section{METHOD}

This study is part of a research project that evaluates the matriculation process, carried out by a team of specialists in health care for older adults receiving care from Family Health Strategy (FHS) teams. The study was observational, transversal and analytical in nature. It was conducted in Montes Claros, in the north of the state of Minas Gerais, which is the main urban hub of the region.

To determine the sample size, an estimated population of 33,930 older adults $(8.2 \%$ of the total population of the city) was considered, along with a frequency of $50 \%$ of older adults with some level of functional impairment (considered to be a conservative frequency, which produces a larger sample number'), a 95\% confidence level and a sampling error margin of $3 \%$. The sampling process was carried out by clusters in two stages. Initially, regional health centers were drawn, followed by at each center, FHS teams and their respective coverage areas. For each territory, the micro-areas defined in the process of territorialization of the health teams were drawn, within which all the older adults were considered eligible for the study. The minimum calculated sample size was 1,035 individuals. This value was multiplied by a correction factor for the design effect ("deff") equal to 1.5 and increased by 
$10 \%$ for eventual losses, which defined a minimum of 1,708 older adults to be evaluated.

The data collection process, carried out between February and October 2017, involved a specially trained team, composed of medical students and nurses. Prior to the beginning of the study, a pilot study was conducted in an area other than those selected for the research, for the final calibration of the team (Kappa Index $>0.8$ for most of the items measured), the data of which were not included in the final work. The questionnaire was applied at the home of the older adults.

All the older adults registered with the FHS teams from the selected micro-areas were considered eligible for the study. Older adults who were unable to answer questionnaires and who did not have a caregiver/guardian available during visits were also excluded. Older individuals who were not present at home after at least three visits, on different days and at different times, even after prior appointments, were considered losses.

Data collection was performed using the Brazilian Older Americans Resources and Services Multidimensional Function Assessment Questionnaire (BOMFAQ). This instrument is a version of the Older Americans Resources and Services (OAR) and consists of a multidimensional assessment of older adults adapted and validated in Brazil $^{10}$. The instrument includes, in addition to functional capacity, sociodemographic data and an assessment of physical and mental health through the Mini Mental State Examination (MMSE) and the Psychogeriatric Tracking Questionnaire (PRT), as well as information on social integration.

Especially in terms of functionality, BOMFAQ evaluates ADLs, investigating the degree of difficulty described in the performance of fifteen daily activities, of which eight are classified as BADLs (lying down/getting up, eating, combing hair, walking on a level surface, showering, dressing, going to the bathroom in time and cutting toenails) and seven are considered IADLs (climbing a flight of stairs, taking medication at the correct time, walking close to home, shopping, preparing meals, going out and cleaning the house).
The existence of difficulty or dependence in carrying out each of these activities was identified according to the BOMFAQ questionnaire. The sum of the difficulties comprised the value of this discrete quantitative variable, with a higher value representing greater impairment, in accordance with the following criterion: no difficulty or independent; difficulty in one to three activities: mild dependence; difficulty in four to six activities: moderate dependency; and difficulty in seven or more activities: severe dependence. To assess the factors associated with functional dependence, the variable was dichotomized into dependent (one or more difficulties) and independent (no difficulty).

The following independent variables were evaluated: sex (male $x$ female), age ( $<70$ years $x$ $\geq 70$ years), marital status (married/stable union $x$ single/widowed/separated), education ( $\leq 4$ years $x>4$ years), currently working (yes x no), family income ( $\leq 1$ minimum wage $\mathrm{x}>1$ minimum wage) regular physical activity (yes x no), smoking (yes x no), habit of walking (yes x no), dancing ( yes x no), playing sports (yes x no), watching television (yes x no), listening to the radio (yes $\mathrm{x}$ no) and reading (yes $x$ no). Data on self-reported morbidities was also collected (rheumatism, asthma or bronchitis, high blood pressure, poor circulation, diabetes, obesity, cataracts, urinary incontinence, insomnia, back problems and osteoporosis), along with self-perceived health (positive $x$ negative), records of falls in the last year (yes x no), and hospitalization in the last six months (yes x no).

Cognitive impairment assessed by the Mini Mental State Examination and its categorization (with cognitive impairment $\mathrm{x}$ without cognitive impairment) was carried out based on the respondent's level of schooling. Thus, cognitive impairment was considered present for people with no schooling with a final score $<13$ points, for people with between one and eight years of schooling with a final score $<18$ points and for those with eight or more years of schooling, with a score $<26$ points. Depressive symptoms, according to the Psychogeriatric Screening Questionnaire, were considered present when the questionnaire reached a final score equal to or greater than six points. 
For data analysis, descriptive statistics were initially applied, followed by bivariate analysis, using the chi-square test. Variables that were associated up to the level of $20 \%$ in the bivariate analysis were evaluated in a hierarchical model using Poisson Regression, with robust variance, to obtain the prevalence ratios (PR) and adjusted confidence intervals $(95 \% \mathrm{CI})$. The quality of the adjustment was assessed by analyzing the deviance and likelihood ratio. For the composition of the hierarchical model, the sequence described in Figure 1 was adopted.

\section{SOCIO-DEMOGRAPHIC VARIABLES}

Sex

Family Income

Age Range

Currently working

Years of Schooling

Marital Status

\section{LIFE HABITS}

Regular physical activity Walking

Play sports

Watch TV

Dance

Listen To The Radio

Current Smoker

Reading

\section{FUNCTIONALITY}

\section{SELF-RELATED MORBIDITY}

Depressive Symptoms

Hospitalizations

in the last 6 months

Impaired Cognition

Diabetes

Self-perceived health

Osteoporosis

Sleep Problems

Fall in the last year

Asthma/Bronchitis

\section{Insomnia}

Cataracts

Obesity

Incontinence

Rheumatism

Spine problems

Poor circulation

High blood

pressure

Figure 1. Model for multiple hierarchical analysis of factors associated with impaired functionality in older adults. Montes Claros, Minas Gerais, 2018. 
All ethical aspects were respected in this study. The participants and their companions were duly informed about the research and agreed to participate by signing an Informed Consent Form (ICF). Fingerprints were collected for those who could not sign. The anonymity and confidentiality of all the information provided were guaranteed, and the data were used exclusively for the purposes of the study. The research project was approved by the Research Ethics Committee of the Universidade Estadual de Montes Claros (Unimontes), under decision $\mathrm{n}^{\mathrm{o}}$ 1.628.652.

\section{RESULTS}

A total of 1,750 older adults aged 60 to 107 years were evaluated. There was a predominance of the 60 to 69 years age group (48.6\%). The female sex represented $63.4 \%$ of the interviews. The majority declared their skin color black or brown (62.8\%). Most of the older adults had not reached high school $(88.5 \%)$, and $11.5 \%$ declared themselves illiterate. In relation to lifestyle, regular physical activity was described by a third of the older adults (33.3\%) and the most mentioned leisure activities were watching television and listening to the radio. These and other characteristics of the group are shown in Table 1.

The largest proportion of the population surveyed in this study was considered dependent in the performance of at least one ADL (57.0\%). The proportion of mild, moderate and severe dependence was $26.5 \%, 12.4 \%$ and $18.1 \%$, respectively.

Table 2 shows the distribution of the evaluated activities and the level of difficulty recorded for each.
The most impaired BADLs were cutting toenails and lying down/getting out of bed. The main impaired IADLs were climbing stairs and cleaning the house.

Tables 3 and 4 show the results of the crude (bivariate) and adjusted analysis for the factors associated with functional dependence, with Table 3 including sociodemographic variables and lifestyle habits and Table 4 including variables related to health conditions. The variables that were found to be statistically associated with some level of functional dependence after multiple analysis were: the female sex $(\mathrm{PR}=1.19 ; 95 \% \mathrm{CI}=1.08-1.31)$; age 70 years or older $(\mathrm{PR}=1.33$; 95\% $\mathrm{CI}=1.22-1.45)$; schooling equal to or less than four years $(\mathrm{PR}=1.19$; 95\% CI=1.08-1.31); not currently working ( $\mathrm{PR}=1.43$; 95\% CI=1.11-1.85); not performing regular physical activity ( $\mathrm{PR}=1.19 ; 95 \% \mathrm{CI}=1.05-1.34)$; not taking walks ( $P R=1.15 ; 95 \% C I=1.01-1.31)$; not listening to the radio as a pastime $(\mathrm{PR}=1.13 ; 95 \% \mathrm{CI}=1.05$ 1.22); not having the habit of reading ( $\mathrm{PR}=1.17$; $\mathrm{CI} 95 \%=1.07-1.28)$; presenting depressive symptoms $(\mathrm{PR}=1.15 ; 95 \% \mathrm{CI}=1.03-1.29)$; having a record of at least one hospitalization in the previous six months ( $P R=1.18$; 95\% CI=1.09-1.26); suffer cognitive impairment $(\mathrm{PR}=1.16$; 95\% $\mathrm{CI}=1.09-1.25)$; reported insomnia ( $\mathrm{PR}=1.13$; 95\% CI=1.04-1.22); obesity $(\mathrm{PR}=1.18$; 95\% $\mathrm{CI}=1.09-1.29)$; having a fall recorded in the previous year ( $\mathrm{PR}=1.11 ; 95 \% \mathrm{CI}=1.04-1.20)$; cataracts $(\mathrm{PR}=1.09 ; 95 \% \mathrm{CI}=1.01-1.18)$, spinal problems $(\mathrm{PR}=1.19$; 95\% $\mathrm{CI}=1.09-1.30)$; urinary incontinence $(\mathrm{PR}=1.25 ; 95 \% \mathrm{CI}=1.16-1.36)$; poor circulation $(\mathrm{PR}=1.09 ; 95 \% \mathrm{CI}=1.01-1.18)$ and having a negative self-perception of health $(\mathrm{PR}=1.22$; CI95\%=1.16-1.28). 
Table 1. Characterization of older adults assisted by Family Health Strategy teams. Montes Claros, Minas Gerais, 2018.

\begin{tabular}{|c|c|c|}
\hline Variables & $\mathrm{n}(\%)$ & $\% *$ \\
\hline \multicolumn{3}{|l|}{ Sex } \\
\hline Male & $641(36.6)$ & 36.6 \\
\hline Feminine & $1109(63.4)$ & 63.4 \\
\hline \multicolumn{3}{|l|}{ Ethnicity/color } \\
\hline White & $630(36.0)$ & 36.0 \\
\hline Black & $219(12.5)$ & 12.5 \\
\hline Mixed-race & $879(50.2)$ & 50.3 \\
\hline Yellow (Asian-Brazilian)/Indigenous & $21(1.2)$ & 1.2 \\
\hline \multicolumn{3}{|l|}{ Age (years) } \\
\hline $60-69$ & $851(48.6)$ & 48.6 \\
\hline $70-79$ & $569(32.5)$ & 32.5 \\
\hline $80-107$ & $330(18.9)$ & 18.9 \\
\hline \multicolumn{3}{|l|}{ Education } \\
\hline Illiterate & $201(11.5)$ & 11.5 \\
\hline 1 - 3 years (Can read/write or incomplete primary) & $587(33.5)$ & 33.6 \\
\hline 4 years (complete primary) & $407(23.3)$ & 23.3 \\
\hline 5 - 8 years (primary II) & $230(13.2)$ & 13.3 \\
\hline$>9$ years (high school or higher) & $324(18.5)$ & 18.5 \\
\hline \multicolumn{3}{|l|}{ Marital status } \\
\hline Not married & $159(9.1)$ & 9.1 \\
\hline Married & $911(52.1)$ & 52.1 \\
\hline Civil partnership & $34(1.9)$ & 1.9 \\
\hline Divorced/separated & $152(8.7)$ & 8.7 \\
\hline Widower & $493(28.2)$ & 28.2 \\
\hline \multicolumn{3}{|l|}{ Family income (minimum wage multiplier) } \\
\hline$\leq 1.0$ & $428(25.9)$ & 25.9 \\
\hline $1.1-3.0$ & $893(54.1)$ & 54.1 \\
\hline 3.1 to 5.0 & $216(13.1)$ & 13.1 \\
\hline$>5.0$ & $114(6.9)$ & 6.9 \\
\hline \multicolumn{3}{|l|}{ Lifestyle Features } \\
\hline Regular Physical Activity & $582(33.3)$ & 33.3 \\
\hline Current smoker & $131(7.5)$ & 7.5 \\
\hline Past smoker & $606(34.7)$ & 34.7 \\
\hline \multicolumn{3}{|l|}{ Leisure activities** } \\
\hline Crafts & $744(43.1)$ & 43.1 \\
\hline Watch TV & $1468(7.5)$ & 84.2 \\
\hline Listen to Radio & $979(56.2)$ & 56.2 \\
\hline Reading & $820(47.2)$ & 47.2 \\
\hline To dance & $167(9.6)$ & 9.6 \\
\hline Play sports & $78(4.5)$ & 4.5 \\
\hline
\end{tabular}

*Percentage weighted by the sample weight; **The sum of the percentages is greater than $100 \%$ because the instrument allows more than one activity to be recorded. 
Table 2. Level of difficulty in performing activities of daily living among older adults cared for by Family Health Strategy teams. Montes Claros, Minas Gerais, 2018.

\begin{tabular}{llll}
\hline Activities of Daily Living & $\begin{array}{l}\text { Great difficulty } \\
\mathrm{n}(\%)\end{array}$ & $\begin{array}{l}\text { Little difficulty } \\
\mathrm{n}(\%)\end{array}$ & $\begin{array}{l}\text { No difficulty } \\
\mathrm{n}(\%)\end{array}$ \\
\hline Basic Activities & & & \\
Lie down on/get up from bed & $144(8.2)$ & $273(15.6)$ & $1332(76.1)$ \\
Eat & $48(2.7)$ & $71(4.1)$ & $1630(93.2)$ \\
Brush hair & $65(3.7)$ & $85(4.9)$ & $1599(91.4)$ \\
Walking on level surface & $134(7.7)$ & $173(9.9)$ & $1442(82.4)$ \\
Take a bath & $118(6.7)$ & $87(5.0)$ & $1544(88.2)$ \\
Dress up & $98(5.6)$ & $124(7.1)$ & $1527(87.3)$ \\
Go to bathroom in time & $94(5.4)$ & $129(7.4)$ & $1526(87.2)$ \\
Instrumental activities & & & $1053(60.2)$ \\
Cut toenails & $422(24.1)$ & $243(13.9)$ & $1107(63.3)$ \\
Climb Stairs & $312(17.8)$ & $330(18.9)$ & $1414(80.8)$ \\
Take medication at correct time & $174(9.9)$ & $161(9.2)$ & $1408(80.5)$ \\
Walk near home & $210(12.0)$ & $131(7.5)$ & $1371(78.3)$ \\
Shopping & $276(15.8)$ & $98(5.6)$ & $1422(81.3)$ \\
Preparing Meals & $230(13.1)$ & $73(4.2)$ & $1315(75.1)$ \\
Drive & $280(16.0)$ & $149(8.5)$ & $1142(65.3)$ \\
Clean the house & $364(20.8)$ & $215(12.3)$ &
\end{tabular}

Table 3. Crude and adjusted analyzes of the associations between sociodemographic variables and life habits and dependence for activities of daily living (ADLs) among older adults cared for by Family Health Strategy teams. Montes Claros, Minas Gerais, 2018.

\begin{tabular}{|c|c|c|c|c|c|}
\hline Variables & $\begin{array}{l}\text { Dependent } \\
\mathrm{n}(\%)\end{array}$ & $\begin{array}{l}\text { Independent } \\
\mathrm{n}(\%)\end{array}$ & $p$-value & Crude $\operatorname{PR}\left(\mathrm{CI}_{95^{\circ}}\right)$ & Adjusted $\mathrm{PR}\left(\mathrm{CI}_{95 \%}\right)^{* *}$ \\
\hline \multicolumn{6}{|c|}{ Sociodemographic variables } \\
\hline Sex & & & $<0.001$ & & \\
\hline Female & $680(61.4)$ & $428(38.6)$ & & $1.24(1.13-1.35)$ & $1,19(1,08-1,31)$ \\
\hline Male & $318(49.6)$ & $323(50.4)$ & & 1 & 1 \\
\hline Age range (years) & & & $<0.001$ & & \\
\hline$\geq 70$ & $599(66.6)$ & $300(33.4)$ & & $1.42(1.30-1.55)$ & $1,33(1,22-1,45)$ \\
\hline$<70$ & $399(46.9)$ & $451(53.1)$ & & 1 & 1 \\
\hline Schooling (years) & & & $<0.001$ & & \\
\hline$\leq 4$ & $733(61.3)$ & $462(38.7)$ & & 1.31(1.19-1.45) & $1,19(1,08-1,31)$ \\
\hline$>4$ & $259(46.8)$ & $295(53.2)$ & & 1 & 1 \\
\hline Marital Status & & & $<0.001$ & & \\
\hline Widowed/unmarried & $510(63.4)$ & $295(36.6)$ & & $1.23(1.13-1.33)$ & * \\
\hline married/civil partnership & $488(51.7)$ & $456(48.3)$ & & 1 & \\
\hline \multicolumn{3}{|c|}{ Family Income (minimum salaries) } & 0.82 & & \\
\hline$\leq 1$ & $260(60.7)$ & $168(39.3)$ & & $1.08(0.99-1.19)$ & $*$ \\
\hline$>1$ & $738(55.9)$ & $583(44.1)$ & & 1 & \\
\hline
\end{tabular}


Continuation of Table 3

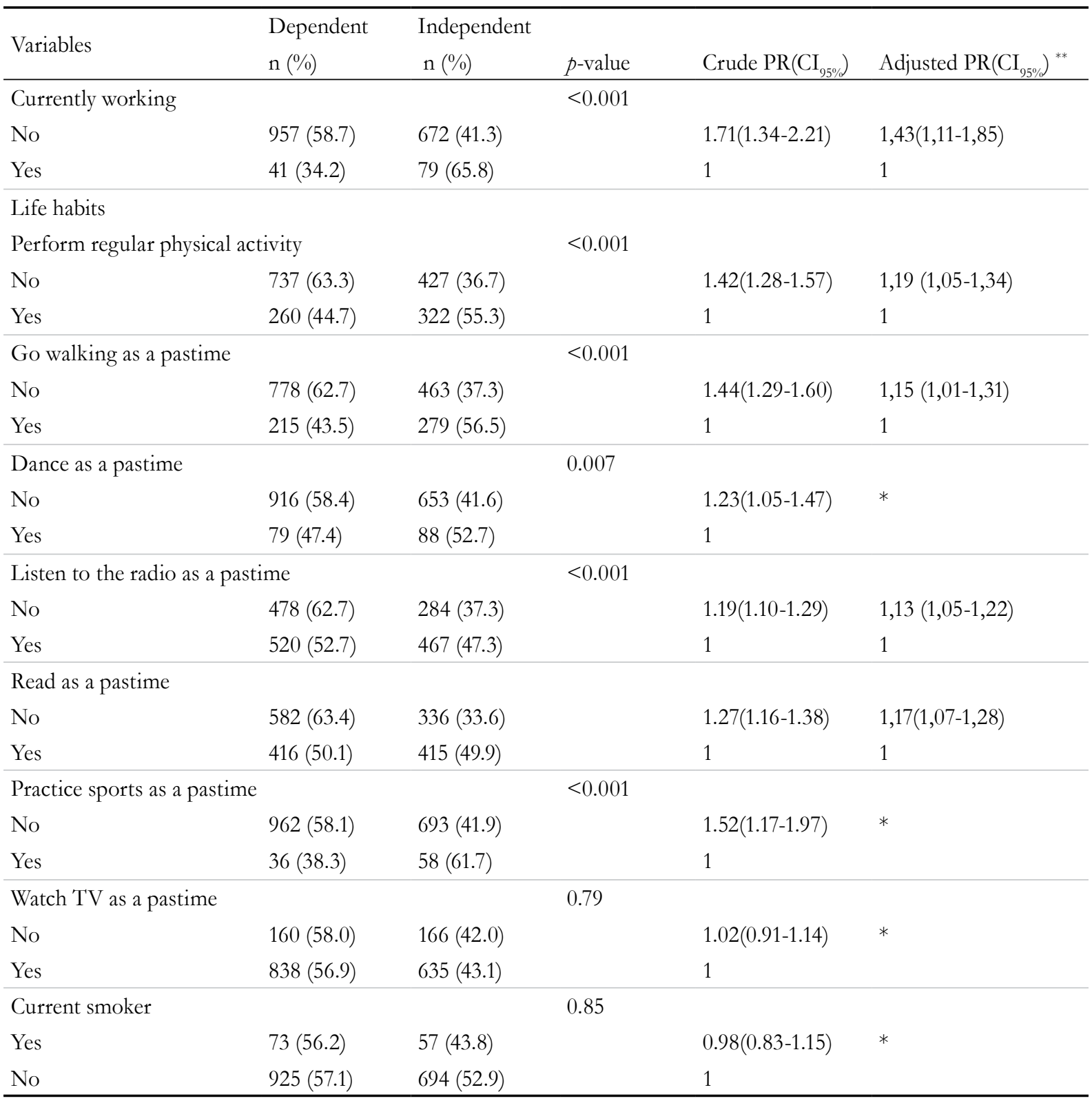

* Excluded after adjustment with other variables (without statistical significance); ${ }^{*} *$ Likelihood ratio (Omnibus test): $p<0.001$.

Table 4. Crude and adjusted analyzes of the associations between variables related to health conditions with dependence for activities of daily living (ADLs) among older adults assisted by Family Health Strategy teams. Montes Claros, Minas Gerais, 2018.

\begin{tabular}{|c|c|c|c|c|c|}
\hline Variables & $\begin{array}{l}\text { Dependent } \\
\mathrm{n}(\%)\end{array}$ & $\begin{array}{l}\text { Independent } \\
\mathrm{n}(\%)\end{array}$ & $p$-value & Crude PR $\left(\mathrm{CI}_{95 \%}\right)$ & Adjusted $\mathrm{PR}\left(\mathrm{CI}_{95 \%}\right){ }^{* * *}$ \\
\hline Depressive Symptoms ** & & & $<0.001$ & & \\
\hline Yes & $97(78.2)$ & $27(21.8)$ & & $1.41(1.27-1.56)$ & $1.15(1.03-1.29)$ \\
\hline No & $901(55.4)$ & $724(44.6)$ & & 1.00 & 1.00 \\
\hline \multicolumn{3}{|c|}{ Hospitalizations in the last 6 months } & $<0.001$ & & \\
\hline Yes & $99(81.8)$ & $22(18.2)$ & & $1.49(1.35-1.63)$ & $1.18(1.09-1.26)$ \\
\hline No & $899(55.2)$ & $729(44.8)$ & & 1.00 & 1.00 \\
\hline
\end{tabular}


Continuation of Table 4

\begin{tabular}{|c|c|c|c|c|c|}
\hline Variables & $\begin{array}{l}\text { Dependent } \\
\mathrm{n}(\%)\end{array}$ & $\begin{array}{l}\text { Independent } \\
\mathrm{n}(\%)\end{array}$ & $p$-value & Crude PR $\left(\mathrm{CI}_{95 \%}\right)$ & Adjusted $\mathrm{PR}\left(\mathrm{CI}_{95 \%}\right)^{* * *}$ \\
\hline Cognition impairment (1 & i-mental) $* * *$ & & $<0.001$ & & \\
\hline Yes & $161(80.1)$ & $40(19.9)$ & & $1.48(1.36-1.61)$ & $1.16(1.09-1.25)$ \\
\hline No & $837(54.1)$ & $711(45.9)$ & & 1.00 & 1.00 \\
\hline High blood pressure & & & $<0.001$ & & \\
\hline Yes & $752(60.7)$ & $486(39.3)$ & & $1.26(1.14-1.39)$ & $*$ \\
\hline No & $246(48.1)$ & $265(51.9)$ & & 1.00 & \\
\hline Diabetes & & & 0.002 & & \\
\hline Yes & $232(64.1)$ & $130(35.9)$ & & $1.16(1.06-1.27)$ & $*$ \\
\hline No & $766(55.2)$ & $621(44.8)$ & & 1.00 & \\
\hline Insomnia & & & $<0.001$ & & \\
\hline Yes & $377(62.6)$ & $142(27.4)$ & & $1.44(1.33-1.55)$ & $1.13(1.04-1.22)$ \\
\hline No & $621(50.5)$ & $609(49.5)$ & & 1.00 & 1.00 \\
\hline Obesity & & & $<0.001$ & & \\
\hline Yes & $227(68.8)$ & $103(31.2)$ & & $1.27(1.16-1.38)$ & 1.18(1.09-1.29) \\
\hline No & $771(54.3)$ & $648(45.7)$ & & 1.00 & 1 \\
\hline Falls in the last year & & & $<0.001$ & & \\
\hline One or more & $369(69.1)$ & $165(30.9)$ & & $1.33(1.23-1.44)$ & $1.11(1.04-1.20)$ \\
\hline None & $629(51.8)$ & $586(48.2)$ & & 1.00 & 1.00 \\
\hline Asthma and Bronchitis & & & 0.160 & & \\
\hline Yes & $92(62.6)$ & $55(37.4)$ & & $1.10(0.97-1.26)$ & $*$ \\
\hline No & $906(56.6)$ & $696(43.4)$ & & 1.00 & \\
\hline Cataract & & & $<0.001$ & & \\
\hline Yes & $286(71.3)$ & $115(28.7)$ & & $1.35(1.25-1.46)$ & $1.09(1.01-1.18)$ \\
\hline No & $712(52.8)$ & $636(47.2)$ & & 1.00 & 1.00 \\
\hline Spine problems & & & $<0.001$ & & \\
\hline Yes & $551(68.2)$ & $257(31.8)$ & & $1.44(1.32-1.56)$ & $1.19(1.09-1.30)$ \\
\hline No & $447(47.5)$ & $494(52.5)$ & & 1.00 & 1.00 \\
\hline Urinary incontinence & & & $<0.001$ & & \\
\hline Yes & $256(84.8)$ & $46(15.2)$ & & $1.65(1.54-1.77)$ & $1.25(1.16-1.36)$ \\
\hline No & $742(51.3)$ & 705 (48.7) & & 1.00 & 1.00 \\
\hline Poor circulation & & & $<0.001$ & & \\
\hline Yes & $486(67.1)$ & $238(32.9)$ & & $1.34(1.24-1.45)$ & $1.09(1.01-1.18)$ \\
\hline No & $512(50.0)$ & $513(50.0)$ & & 1.00 & 1.00 \\
\hline Osteoporosis & & & $<0.001$ & & \\
\hline Yes & $92(70.8)$ & $38(29.2)$ & & $1.26(1.12-1.42)$ & $*$ \\
\hline No & $906(56.0)$ & $713(44.0)$ & & 1.00 & \\
\hline Rheumatism & & & $<0.001$ & & \\
\hline Yes & $250(71.6)$ & $99(28.4)$ & & $1.34(1.23-1.46)$ & $*$ \\
\hline No & 748 (53.4) & $652(46.6)$ & & 1.00 & \\
\hline Self-perceived health & & & $<0.001$ & & \\
\hline Negative & $387(75.7)$ & $124(24.3)$ & & $1.53(1.42-1.65)$ & $1.22(1.16-1.28)$ \\
\hline Positive & $611(49.4)$ & $627(50.6)$ & & 1.00 & 1.00 \\
\hline
\end{tabular}

*Excluded after adjustment with other variables (with no statistical significance); ${ }^{* * S}$ screening for depressive disorder using the PRT questionnaire; $* * *$ Screening for dementia symptoms using the mini mental Bertolucci score; ****Likelihood ratio (Omnibus test): $p<0.001$ 


\section{DISCUSSION}

The present study identified a high prevalence of functional dependence among the older adults receiving care from the FHS teams $(57.0 \%)$. The analysis of the factors associated with the occurrence of functional dependence for the evaluated group highlights the fact that it is a multifactorial event and that it is especially influenced by health conditions, and involves several functional systems (cognition, mood/behavior, mobility and communication). International literature registers very different values for the assessment of functional dependence among older adults, with values ranging from $6.6 \%$ to $92.0^{11,12}$. These disparate values must be carefully evaluated, as they are almost always the result of specific analyzes of the older adults and involve different populations or the use of different instruments for measuring or defining the studied event. The prevalence of $92.0 \%$, for example, portrays a nonagenarian population ${ }^{12}$.

In Brazil, in a study conducted in the interior of São Paulo, the authors recorded that $8.49 \%$ of the older adults were functionally dependent for BADLs and $10.96 \%$ for IADLs ${ }^{13}$. Another population-based survey conducted in Rio Grande do Sul found a prevalence of incapacity of $10.6 \%$ for basic activities and $34.2 \%$ for instrumental activities ${ }^{14}$. However, both studies used different scales to that used in the present study.

In other countries, the results of studies using a more similar population and instruments recorded higher results of functional impairment. In Poland, prevalences of $36.85 \%$ and $43.19 \%$ were found for BADLs and IADLs, respectively ${ }^{15}$ while in Mexico, among older adults in the community, a prevalence of $31.3 \%$ was identified for dependence in IADLs ${ }^{16}$. Even so, the values observed in the present study identified a higher level of functional dependence, which should serve as a warning for local health professionals and managers.

Among the demographic variables, the present study identified an association with the female sex, age over 70 years, low levels of schooling and not currently working. The higher prevalence of functional impairment among women has been pointed out in other studies ${ }^{17,18}$, while there is a consensus in literature in relation to more advanced

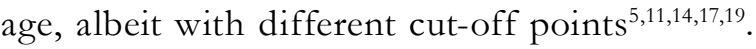
Other studies have also registered the association between functional incapacity and low levels of education ${ }^{14,17,19,20}$. The findings can be explained by: greater levels of survival and the prevalence of non-fatal disabling conditions among women (osteoporosis, cataracts and diabetes, for example) as well as the fact that women report greater functional difficulties than men $^{18}$. The difficulty in accessing education can result in risk factors for diseases and poorer working conditions, making it difficult to acquire healthy life habits ${ }^{20}$. Also, not currently working may be the result of the limitations imposed by functional impairment or by greater age, which would lead to retirement ${ }^{21}$.

A study carried out with a population resident in the community identified a higher risk of functional dependence in older adults aged $\geq 80$ years, the use of two or more medications and cognitive impairment ${ }^{22}$. Another Brazilian study reported that older adults who live alone have a worse state of health and health-related habits, with a higher prevalence of functional dependence associated with instrumental activities of daily living ${ }^{23}$. In the present study, an association with marital status was not observed. Similarly, family income was also not associated, a fact that may be the result of the more uniform characteristics of the assessed population, which is a group of older adults registered with FHS teams.

In relation to life habits, the present study identified that physical inactivity, assessed by selfreported physical inactivity or the absence of the habit of walking regularly, has a direct impact on functional dependence. Other studies have shown that regular physical activity is associated with a better state of functionality and quality of life for older adults ${ }^{24,25}$. Regular physical activity attenuates and reverses the loss of muscle mass contributing to the control of stress, obesity, diabetes and the improved functional fitness of older adults ${ }^{26,27}$. Leisure activities such as listening to the radio and reading were statistically associated with the studied event. Although investigations of such variables have not been identified in literature, the Epidoso study 
concluded that leisure activities should be valued, as they have a protective effect on the functionality of older adults ${ }^{28}$. It is also possible that these data indicate that the older adults are more involved with their environment and have better cognitive conditions.

In relation to self-reported morbidities, those that maintained statistical significance, after multiple regression analysis, were: insomnia, obesity, cataracts, spinal problems, urinary incontinence and poor circulation. Chronic diseases had a strong impact on the functionality of the older adults. Some of these conditions have already been associated with functional dependence ${ }^{15,20,29,30}$. In a Spanish study, the authors reported that individuals suffering from more than one chronic disease were around twice as likely to be functionally dependent for ADLs and IADLs ${ }^{30}$.

The present study identified a relationship between depressive symptoms and a higher prevalence of functional dependence, similar to the findings of another study ${ }^{31}$. This is a natural association, considering that this is a multifactorial disorder of the affective area and mood, involving biological, psychological and social aspects. A worse cognitive performance, measured by the Mini Mental State Examination in this study, was associated with impaired functionality, a finding reinforced in other studies $^{11,14,30,32}$. This may be associated not only with the fact that cognition is integrated in one of the domains of the test, but also because it contributes to preserve functionality.

A history of falls in the previous year was also associated with functional dependence, after the adjusted analysis. Falls represent a serious problem for older adults and are related to high rates of morbidity and mortality and reduced mobility and the limited performance of several ADLs. A study using the same BOMFAQ instrument showed an increase in the difficulty of performing ADLs, in proportion to the number of previous falls ${ }^{33}$. In a prospective study conducted in São Paulo ${ }^{34}$, there was a worsening of functional dependence after hospitalization, which is compatible with the data from the present study.
A negative self-perception of health was also shown to be associated with functional dependence. It seems natural that more pessimistic responses in the assessment of self-perceived health are associated with functional dependence. This variable is associated with morbidity and mortality in addition to limitations in $\mathrm{ADL}^{35}$. On the other hand, positive self-assessments of health are predictors of healthy aging ${ }^{36}$.

The results of the present study must be considered in the light of certain limitations. It is a study with a population receiving care from FHS teams and, therefore, the results cannot be generalized to the entire older population. It is, however, the most vulnerable population and the one that demands the greatest care. As it is a cross-sectional study, it is not possible to establish causal relationships. Considering that a lot of information was self-reported, it is possible that memory limitations have affected the measured data. On the other hand, validated instruments were used and the sampling allocation process defined good representativeness among the studied group, and few losses were recorded.

\section{CONCLUSION}

The study identified a high proportion of older adults with functional impairment. The variables statistically associated with functional dependence, after regression analysis, highlight the role of some self-reported morbidities and involve the various functional systems (cognition, mood/behavior, mobility and communication). Therefore, an expanded and updated perspective is necessary, so that the multidisciplinary team of the Family Health Strategy (FHS), can treat this group of older adults more effectively. These aspects must be reinforced in the formulation of government health promotion policies. Health care strategies for older adults should guarantee access to comprehensive and long-term services focused on the requirements of this public, aligning health systems to their needs, with a focus on multiprofessional care, as this can have a positive effect on the functional capacity of this population. 
Health for the older population is closely linked to functionality, which includes the potential for managing one's own life or taking care of oneself. The present study is of particular importance as it evaluates the functional dependence of older adults residing in a community environment receiving care from FHS teams. Although some determinants in the functionality of older adults are genetic, many are related to the physical and social environment in which they live, as well as personal characteristics such as sex, ethnicity or socioeconomic conditions.

Edited by: Tamires Carneiro Oliveira Mendes

\section{REFERENCES}

1. World Health Organization. Global strategy and action plan on ageing and health. Geneva: WHO; 2017.

2. Miranda GMD, Mendes ACG, Silva ALA. O envelhecimento populacional brasileiro: desafios e consequências sociais atuais e futuras. Rev Bras Geriatr Gerontol. 2016;19(3):507-19.

3. Veras RP. Envelhecimento populacional e as informações de saúde do PNAD: demandas e desafios contemporâneos. Cad Saúde Pública. 2007;23(1):2463-6.

4. Burlá C, Camarano AA, Kanso S, Fernandes D, Nunes R. Panorama prospectivo das demências no Brasil: um enfoque demográfico. Ciênc Saúde Colet. 2013;18(1):2949-56.

5. Del Duca GF, Silva MCD, Hallal PC. Incapacidade funcional para atividades básicas e instrumentais da vida diária em idosos. Rev Saúde Pública. 2009;43(5):796-805.

6. Lopes G, Santos M. Funcionalidade de idosos cadastrados em uma unidade da Estratégia Saúde da Família segundo categorias da Classificação Internacional de Funcionalidade. Rev Bras Geriatr Gerontol. 2015;18(1):71-83.

7. Veras RP, Oliveira M. Envelhecer no Brasil: a construção de um modelo de cuidado. Ciênc saúde colet 2018;23(6):1929-36.

8. Veras RP. Linha de cuidado para o idoso: detalhando o modelo. Rev Bras Geriatr Gerontol. 2016;19(6):887-905.

9. Medronho RA, Bloch KA, Luiz RR, Werneck GL. Epidemiologia. 2. ed. Rio de Janeiro: Atheneu, 2009.

10. Blay SL, Ramos, LR, de Mari JJ. Validity of a Brazilian version of the Older Americans Resources and Services (OARS) mental health screening questionnaire. J Am Geriatr Soc. 1988;36(8):687-92.

11. Ng TP, Niti M, Chiam PC, Kua EH. Prevalence and correlates of functional disability in multiethnic elderly singaporeans. J Am Geriatr Soc. 2006;54(1):21-9.
12. Berlau DJ, Corrada MM, Kawas C. The prevalence of disability in the oldest-old is high and continues to increase with age: findings from The $90+$ Study. Int J Geriatr Psychiatry. 2009;24(11):1217-25.

13. Kagawa C, Corrente J. Análise da capacidade funcional em idosos do município de Avaré-SP: fatores associados. Rev Bras Geriatr Gerontol. 2015;18(3):577-86

14. Nunes JD, Saes MO, Nunes BP, Siqueira FCV, Soares DC, Fassa MEG, et al. Indicadores de incapacidade funcional e fatores associados em idosos: estudo de base populacional em Bagé, Rio Grande do Sul. Epidemiol Serv Saúde. 2017;26(1):295-304.

15. Cwirlej-Sozańska A, Sozański B, Wiśniowska-Szurlej A, Wilmowska-Pieturuszyńka A. An assessment of factors related to disability in ADL and IADL in elderly inhabitants of rural areas of south-eastern Poland. Ann Agric Environ Med. 2018;25(3):504-11.

16. Cervantes Becerra RG, Villarreal Ríos E, Galicia Rodriguez L, Vargas Daza ER, Martínez González L. Estado de salud en el adulto mayor en atención primaria a partir de una valoración geriátrica integral. Aten Prim. 2015;47(6):329-35.

17. Assis VG, Marta SN, de Conti MHS, Gatti MAN, Simeão SFDSP, de Vitta A. Prevalência e fatores associados à capacidade funcional de idosos na Estratégia Saúde da Família em Montes Claros, Minas Gerais, Brasil. Rev Bras Geriatr Gerontol. 2015;17(1):153-63.

18. Campos ACV, Almeida MHM, Campos GV, Bogutchi TF. Prevalência de incapacidade funcional por gênero em idosos brasileiros: uma revisão sistemática com metanálise. Rev Bras Geriatr Gerontol. 2016;19(3):545-59.

19. Ballesteros SM, Moreno-Montoya J. Individual and state-level factors associated with functional limitation prevalence among Colombian elderly: a multilevel analysis. Cad Saúde Pública. 2018;34(8):e00163717 [12 p.]. 
20. Machado A, Vieira MCU. Impacto de fatores socioeconômicos na funcionalidade da pessoa idosa portadora de condições crônicas. Rev Enferm UFSM. 2015;5(1):81-91.

21. Costa AMMR, Moraes PF, Costa JLR, Lopes RGC. Envelhecimento e trabalho. In: Costa JLR, Costa AMMR, Fuzaro Júnior G, Organizadores. O que vamos fazer depois do trabalho?: reflexões sobre a preparação para aposentadoria. São Paulo: Cultura Acadêmica; 2016. p. 23-32.

22. Freitas RS, Fernandes MH, Coqueiro RS, Reis Júnior WM, Rocha SV, Brito TA. Capacidade funcional e fatores associados em idosos: estudo populacional. Acta Paul Enferm. 2012;25(6):933-9.

23. Negrini ELD, Nascimento CF, Silva A, Antunes JLF. Quem são e como vivem os idosos que moram sozinhos no Brasil. Rev Bras Geriatr Gerontol. 2018;21(5):523-31.

24. Neto MG, Mayan M, Caldas L, Laine C, Amorin P. Estudo comparativo da funcionalidade e qualidade de vida entre idosos de diferentes classes econômicas. Fisioter Bras. 2017;18(5):541-6.

25. Roma MFB, Busse AL, Betoni RA, Melo AC, Kong J, Santarem JM, et al. Efeitos das atividades físicas resistidas e aeróbia em idosos em relação à aptidão física e à funcionalidade: ensaio clínico prospectivo. Einstein. 2013;11(2):153-7.

26. Leinonen R, Heikkinen E, Jylha M. Changes in health, functional performance and activity predict changes in self-rated health: a 10-year follow-up study in older people. Arch Gerontol Geriatr. 2002;35(1):79-92.

27. Bocalini DS, dos Santos L, Serra AJ. Physical exercise improves the functional capacity and quality of life in patients with heart failure. Clinics. 2008;64:437-42.

28. D’Orsi E, Xavier AJ, Ramos LR. Work, social support and leisure protect the elderly from functional loss: Epidoso Study. Rev Saúde Pública. 2011;45(4):685-92.
29. Gomes-Neto M, Araujo AD, Junqueira IDA, Oliveira D, Brasileiro A, Arcanjo FL. Estudo comparativo da capacidade funcional e qualidade de vida entre idosos com osteoartrite de joelho obesos e não obesos. Rev Bras Reumatol. 2016;56(2):126-30.

30. Millán-Calenti JC, Tubío J, Pita-Fernández S, Gon zález-Abraldes I, Lorenzo T, Fernández-Arruty T, et al. Prevalence of functional disability in activities of daily living (ADL), instrumental activities of daily living (IADL) and associated factors, as predictors of morbidity and mortality. Arch Gerontol Geriatr. 2010;50(3):306-10.

31. Paredes-Arturo YV, Yarce-Pinzón E, AguirreAcevedo DC. Funcionalidad y factores asociados en el adulto mayor de la ciudad San Juan de Pasto, Colombia. Rev Cienc Salud. 2018;16(1):114-28.

32. Marra TA, Pereira LSM, Faria CDCM, Pereira DS, Martins MAA, Tirado MGA. Avaliação das atividades de vida diária de idosos com diferentes níveis de demência. Rev Bras Fisioter. 2007;11(4):267-73.

33. Ricci NA, Gonçalves DDFF, Coimbra IB, Coimbra AMV. Fatores associados ao histórico de quedas de idosos assistidos pelo Programa de Saúde da Família. Saúde Soc. 2010;19(4):898-909.

34. Carvalho TC, Valle AP, Jacinto AF, Mayoral VFS, Boas PJFV. Impacto da hospitalização na funcionalidade de idosos: estudo de coorte. Rev Bras Geriatr Gerontol. 2018;21(2):134-42.

35. Medeiros FL, Xavier AJ, Schneider IJC, Ramos LR, Sigulem D, D’Orsi E. Inclusão digital e capacidade funcional de idosos residentes em Florianópolis, Santa Catarina, Brasil, (EpiFloripa 2009-2010). Rev Bras Epidemiol. 2012;15(1):106-22.

36. Confortin SC, Giehl MWC, Antes DL, Schneider IJC, D’Orsi E. Autopercepção positiva de saúde em idosos: estudo populacional no Sul do Brasil. Cad Saúde Pública. 2015;31(5):1049-60. 